\title{
PREPARATION OF BIO-POLYMERIC MATERIALS, THEIR MICROSTRUCTURES AND PHYSICAL FUNCTIONALITIES
}

\author{
PRIPRAVA BIOPOLIMERNIH MATERIALOV TER NJIHOVE \\ MIKROSTRUKTURE IN FIZIČNE FUNKCIONALNOSTI
}

\author{
Xiu-Li Chen, Ai-Juan Zhao, Hai-Jie Sun, Xian-Ru Pei \\ Zhengzhou Normal University, Institute of Environmental and Catalytic Engineering, College of Chemistry and Chenical Engineering, \\ Zhengzhou 450044, China \\ katiloudy@163.com, sunhaijie406@zznu.edu.cn
}

Prejem rokopisa - received: 2015-07-09; sprejem za objavo - accepted for publication: 2016-05-13

doi: $10.17222 / \mathrm{mit} .2015 .211$

\begin{abstract}
In this work, three kinds of bio-based aromatic triols were prepared based on vegetable oils. Furthermore, PUs were synthesized using the three triols and 4,4'-methylenebis(phenyl isocyanate), 1,4-butanediol as a chain extender. The chemical structures, molecular characteristics, and physical functionalities were studied and compared using nuclear magnetic resonance (NMR) spectroscopy, Fourier-transform infrared (FTIR) spectroscopy, X-ray diffraction (XRD), differential scanning calorimetry (DSC), and thermogravimetry-differential thermal analysis (TG-DTA). Results showed that the poly-(oxypropylene)-based polyurethanes degrade in a single step, whereas the vegetable-oil-based polyurethane shows one-step decomposition. The present study therefore suggests a feasible synthesis route for the use of the biomaterials for the production of polyurethanes.

Keywords: polymers, microstructures, functionalities

$\mathrm{V}$ delu so bili iz bioolj prvič pripravljeni trije bioaromatični trioli. Poleg tega so bili sintetizirani PU, z uporabo treh triol in 4,4'-metilenbis(fenil izocianata) ter 1,4-butandiola kot podaljševalca verige. Studirane so bile kemijske strukture, molekularne značilnosti in fizične funkcionalnosti, ki so bile primerjane $\mathrm{z}$ uporabo spektroskopije jedrske magnetne resonance (NMR), spektroskopijo Fourierjeve infrardeče transformacije (NMR), rentgenske difrakcije (XRD), diferenčne vrstične kalorimetrije (DSC) in termogravimetrične diferenčne termične analize (TG-DTA). Rezultati so pokazali, da poliuretan na osnovi poli-oksipropilena razpade $\mathrm{v}$ enem koraku, medtem ko poliuretan na osnovi rastlinskih olj, kaže enostopenjski razpad. Predstavljena študija torej predlaga izvedljivo sintezo z uporabo biomaterialov za izdelavo poliuretanov.

Ključne besede: polimeri, mikrostrukture, funkcionalnosti
\end{abstract}

\section{INTRODUCTION}

In order to protect the environment and to reduce our dependence on fossil fuels, a great deal of research effort has been, and is still being, devoted to the development of innovative technologies using renewable resources. ${ }^{1-7}$ Vegetable oils are abundant and cheap renewable resources that represent a major potential alternative source of chemicals suitable for developing safe, environmentally products. ${ }^{8-10}$ The use of vegetable oils and natural fatty acids as starting raw materials offers numerous advantages: for example, inexpensive, abundant, low toxicity, and inherent biodegradability, thus they are considered to be one of the most important classes of renewable resources for the production of bio-based polymeric materials. ${ }^{1-17}$ Polyurethanes (PUs) form a versatile class of polymers, which are used in a broad range of applications, for example, as elastomers, sealants, fibers, foams, coatings, adhesives, and biomedical materials. The industrial production of PUs is normally accomplished through the polyaddition reaction between organic isocyanates and compounds containing active hydroxyl groups, such as polyols. Comparing with polyurethanes derived from petrochemical polyols, the vegetable-oil-based polyols used to produce polyurethanes have been the subject of many studies..$^{9-12}$ Moreover, due to the hydrophobic nature of triglycerides, vegetable oils produce PUs that have excellent chemical and physical properties, such as enhanced hydrolytic, high tensile strength and elongation, high tear strength, and thermal stability. ${ }^{13-18}$

Vegetable oils are one of the most important sources of renewable raw materials for the chemical industry and provide versatile opportunities for a transformation to meet specific applications. In the 1980s, H. Baumann et al. ${ }^{10}$ mainly focused on the carboxyl group of fatty acids, these include the hydrolysis of fats to make soaps, and synthesis of fatty amines from fatty acids. Recently, increasing interest in industrial and academic research has been focused on reactions on the hydrocarbon chains of fatty acids, especially on the double bonds of unsaturated fatty acids. Guo et al. applied the epoxidation of the double bonds of fatty acids, followed by nucleophilic ring opening of the epoxide to make polyols for producing polyurethanes. ${ }^{19-23}$

To further expand applications of the bio-based polymeric materials, previous studies were focusing on converting vegetable oils into useful PUs. Based on these studies, now it has become a main research field to functionalize vegetable oils by the introduction of aromatic 
X. L. CHEN et al.: PREPARATION OF BIO-POLYMERIC MATERIALS, THEIR MICROSTRUCTURES ...

co-monomers into the polymer structure, which could be suitable in the search for new viable polymeric materials. ${ }^{12}$ The transition-metal-catalyzed trimerization of alkyne fatty acid compounds provides an alternative method for the preparation of highly functionalized aromatic polyols. ${ }^{10,11}$

In the present study, we have synthesized three kinds of bio-based aromatic triols prepared by oleic acid, 10-undecenoic acid, and erucic acid, which could be obtained from sunflower oil, castor oil, and rapeseed oil, respectively. PUs were synthesized by these aromatic triols and 4,4'-methylenebis(phenyl isocyanate), 1,4-butanediol as a chain extender. The chemical structures, molecular characteristics, physical properties, and thermal properties were studied and compared using nuclear magnetic resonance (NMR) spectroscopy, Fourier-transform infrared (FTIR) spectroscopy, X-ray diffraction (XRD), differential scanning calorimetry (DSC), and thermogravimetry-differential thermal analysis (TGDTA).

\section{EXPERIMENTAL PART}

\subsection{Materials}

The following chemicals were obtained from the sources indicated: Oleic acid (AR, from Sinopharm) 10-undecenoic acid (from Sinopharm), erucic acid (from Aldrich), copper (II) chloride, $\mathrm{CuCl}_{2}$ (99\%, from Sinopharm), palladium (II) chloride, $\mathrm{PaCl}_{2}$ (AR, from Sinopharm), palladium on carbon, $\mathrm{Pa} / \mathrm{C}$ (10\% of mass fractions, from Aldrich), potassium hydroxide, $\mathrm{KOH}$ (AR, from Kermel), n-propanol (AR, from Kermel), dimethyl sulfoxide, DMSO (AR, from Kermel), bromine (AR, from Xilong), chlorotrimethylsilane, TMSCl (CP, from Sinopharm), lithium aluminum hydride, $\mathrm{LiAlH}_{4}$ (97\%, from Aldrich), 1,4-butandiol, BD (AR, from Bodi) and 4,4'-methylenebis(phenyl isocyanate), MDI (98\%, from Aldrich) were used as received.

\subsection{Synthesis of aromatic triol 4 from oleic acid}

\subsubsection{Dibromide carboxylic acid}

To a solution of oleic acid $(10.6 \mathrm{~g}, 33.6 \mathrm{~m} / \mathrm{mol})$ in diethyl ether $(150 \mathrm{~mL})$ that was cooled to $0{ }^{\circ} \mathrm{C}$ in an ice-water bath, bromine $(2.7 \mathrm{~mL}, 52.3 \mathrm{~m} / \mathrm{mol})$ was added dropwise over $30 \mathrm{~min}$. Then the ice-water bath was removed and the solution was stirred for another $2 \mathrm{~h}$ at room temperature. A saturated sodium sulfite $\left(\mathrm{Na}_{2} \mathrm{~S}_{2} \mathrm{O}_{3}\right)$ solution $(20 \mathrm{~mL})$ was added to reduce the excess bromine. The resulting organic phase was separated, washed with brine $(20 \mathrm{~mL})$ and dried over anhydrous magnesium sulfate $\left(\mathrm{MgSO}_{4}\right)$. The solvent was evaporated by reduced pressure to give a pale yellow powder 1 (yield $73 \%$ ).

IR (thin film): $3440(\mathrm{OH}), 1703(\mathrm{C}=\mathrm{O}) \mathrm{cm}^{-1}$.

${ }^{1} \mathrm{H}$ NMR ( $\left.\mathrm{CDCl}_{3} / \mathrm{TMS}, \delta, 0.0001 \%\right): 11.34(\mathrm{~s}, 1 \mathrm{H}$, $\mathrm{COOH}), 4.23-4.14$ (m, 2H, CH-Br), 2.38-2.33 (t, $2 \mathrm{H}$, $\mathrm{CH}_{2}-\mathrm{COOH}$ ), 2.06-1.99 (m, 2H, CH-CHBr), 1.88-1.80 (m, 2H, CHBr), 1.64-1.56 (m, 6H), 1.35-1.25 (m, 16H), $0.88\left(\mathrm{t}, 3 \mathrm{H}, \mathrm{CH}_{3}\right)$.

\subsubsection{Stearolic acid}

The dibromide compound $1(5.5 \mathrm{~g}, 15 \mathrm{~m} / \mathrm{mol})$ was dissolved in DMSO (18 mL, $250 \mathrm{mmol})$. KOH (20 g, $360 \mathrm{~m} / \mathrm{mol})$ and 1-propanol $(150 \mathrm{~mL})$ were added. The mixture was heated at $110{ }^{\circ} \mathrm{C}$ under reflux for $4 \mathrm{~h}$. Then the solution was poured into $2 \mathrm{~N}$ hydrochloric acid $(\mathrm{HCl})$ $(150 \mathrm{~mL})$ at room temperature. The resulting organic layer was separated, washed with brine $(20 \mathrm{~mL})$ and dried over $\mathrm{MgSO}_{4}$. The solvent was evaporated under reduced pressure to give a pale-yellow powder 2 (yield $76 \%)$.

IR (thin film): $3446(\mathrm{OH}), 2356(\mathrm{C} \equiv \mathrm{C}), 1712(\mathrm{C}=\mathrm{O})$ $\mathrm{cm}^{-1}$.

${ }^{1} \mathrm{H}$ NMR ( $\left.\mathrm{CDCl}_{3} / \mathrm{TMS}, \delta, 0.0001 \%\right): 11.34(\mathrm{~s}, 1 \mathrm{H}$, $\mathrm{COOH}), 2.33\left(\mathrm{t}, 2 \mathrm{H}, \mathrm{CH}_{2}-\mathrm{COOH}\right), 2.12(\mathrm{~m}, 4 \mathrm{H}$, $\left.\mathrm{CH}_{2}-\mathrm{CC}\right), 1.26-1.62(\mathrm{~m}, 22 \mathrm{H}), 0.88\left(\mathrm{t}, 3 \mathrm{H}, \mathrm{CH}_{3}\right)$

\subsubsection{Stearoyl alcohol}

Stearolic acid $2(2.4 \mathrm{~g}, 8.6 \mathrm{~m} / \mathrm{mol})$ was dissolved in $50 \mathrm{~mL}$ diethyl ether and added dropwise to a dispersion of $\mathrm{LiAlH}_{4}(0.4 \mathrm{~g}, 10.2 \mathrm{~m} / \mathrm{mol})$ in $100 \mathrm{~mL}$ of anhydrous diethyl ether. The mixture was stirred for $2 \mathrm{~h}$ at room temperature, and then the excess $\mathrm{LiAlH}_{4}$ was decomposed by adding $20 \mathrm{~mL}$ of water dropwise. A $2 \mathrm{~N} \mathrm{HCl}$ $(30 \mathrm{~mL})$ aqueous solution was added until the $\mathrm{pH}$ was neutral. The resulting organic layer was separated, washed with brine $(20 \mathrm{~mL})$ and dried over $\mathrm{MgSO}_{4}$. The solvent was evaporated under reduced pressure to give a pale-yellow oil 3 (yield $82 \%$ ).

IR (thin film): $3392(\mathrm{OH}), 2360(\mathrm{C} \equiv \mathrm{C}) \mathrm{cm}^{-1}$.

${ }^{1} \mathrm{H} \mathrm{NMR}\left(\mathrm{CDCl}_{3} / \mathrm{TMS}, \delta, 0.0001 \%\right): 3.65(\mathrm{t}, 2 \mathrm{H}$, $\left.\mathrm{CH}_{2} \mathrm{OH}\right), 2.14\left(\mathrm{t}, 4 \mathrm{H}, \mathrm{CH}_{2}-\mathrm{CC}\right), 1.58-1.48(\mathrm{~m}, 6 \mathrm{H})$, 1.41-1.23(m, 18H), $0.90\left(\mathrm{t}, 3 \mathrm{H}, \mathrm{CH}_{3}\right)$.

\subsubsection{Aromatic triols}

Stearoyl alcohol $3(1.05 \mathrm{~g}, 4.0 \mathrm{~m} / \mathrm{mol})$ was dissolved in tetrahydrofuran (THF) $(50 \mathrm{~mL}) .0 .25 \mathrm{~g}$ of $\mathrm{Pd} / \mathrm{C}(10 \%$ of mass fractions) and TMSCl $(0.75 \mathrm{~mL}, 6.0 \mathrm{~m} / \mathrm{mol})$ were added. The reaction mixture was heated at $65{ }^{\circ} \mathrm{C}$ refluxed for $8 \mathrm{~h}$. The resulting mixture was cooled to room temperature and filtered to remove the $\mathrm{Pd} / \mathrm{C}$. The resulting organic layer was separated, washed with brine $(20 \mathrm{~mL})$ and dried over $\mathrm{MgSO}_{4}$. The solvent was evaporated under reduced pressure to give a dark-yellow oil $4 \mathrm{a}$ and $4 \mathrm{~b}$ (yield $58 \%$ ).

IR (thin film): $3438(\mathrm{OH}), 1652(\mathrm{C}=\mathrm{C}$ of benzene) $\mathrm{cm}^{-1}$.

${ }^{1} \mathrm{H}$ NMR $\left(\mathrm{CDCl}_{3} / \mathrm{TMS}, \delta, 0.0001 \%\right): 3.56(\mathrm{t}, 6 \mathrm{H}$, $\left.\mathrm{CH}_{2} \mathrm{OH}\right), 2.43\left(\mathrm{~m}, 12 \mathrm{H}, \mathrm{CH}_{2} \mathrm{Ph}\right), 1.49-1.20(\mathrm{~m}, 72 \mathrm{H})$, $0.83(\mathrm{t}, 9 \mathrm{H})$.

${ }^{13} \mathrm{C} \mathrm{NMR}\left(\mathrm{CDCl}_{3} / \mathrm{TMS}, \delta, 10^{-4} \%\right): 136.77\left(\mathrm{Ph}-\mathrm{CH}_{2}\right)$, $62.94\left(\mathrm{CH}_{2} \mathrm{OH}\right), 31.94,31.86,29.68,29.64,29.57$, $29.33,29.26,25.72,22.68,22.66,14.12\left(\mathrm{CH}_{3}\right)$. 


\subsection{Synthesis of aromatic triol 4' from 10-undecenoic acid}

\subsubsection{Dibromide carboxylic acid 1'}

10 -Undecylenic acid $(9.2 \mathrm{~g}, 50 \mathrm{~m} / \mathrm{mol})$ in diethyl ether $(150 \mathrm{~mL})$ was cooled to $0{ }^{\circ} \mathrm{C}$ in an ice-water bath. Bromine $(4.2 \mathrm{~mL}, 81 \mathrm{~m} / \mathrm{mol})$ was added dropwise over $30 \mathrm{~min}$. Then the ice-water bath was removed and the solution was stirred for another $2 \mathrm{~h}$ at room temperature. A saturated $\mathrm{Na}_{2} \mathrm{~S}_{2} \mathrm{O}_{3}$ solution $(20 \mathrm{~mL})$ was added to reduce the excess bromine. The resulting organic phase was separated, washed with brine $(20 \mathrm{~mL})$ and dried over $\mathrm{MgSO}_{4}$. The solvent was evaporated under reduced pressure to give a gray solid 1' (yield $78 \%$ ).

IR (thin film): $3433(\mathrm{OH}), 1705(\mathrm{C}=\mathrm{O}) \mathrm{cm}^{-1}$.

${ }^{1} \mathrm{H}$ NMR $\left(\mathrm{CDCl}_{3} / \mathrm{TMS}, \delta, 0.0001 \%\right): 11.58(\mathrm{~s}, 1 \mathrm{H}$, $\mathrm{COOH}$ ), 3.85-3.80 (q, 1H, CH-CHBr), 3.64-3.57 (t, 2H, $\mathrm{CH}-\mathrm{Br}), 2.35-2.30\left(\mathrm{t}, 2 \mathrm{H}, \mathrm{CH}_{2}-\mathrm{COOH}\right), 2.17-2.05$ (m, $3 \mathrm{H}), 1.84-1.50(\mathrm{~m}, 3 \mathrm{H}), 1.30-1.23(\mathrm{~m}, 8 \mathrm{H})$.

\subsubsection{0-Undecynic acid 2'}

The dibromide compound 1' (5.2 g, $15 \mathrm{~m} / \mathrm{mol})$ was dissolved in DMSO (18 mL, $250 \mathrm{mmol}) . \mathrm{KOH}(20 \mathrm{~g}$, $360 \mathrm{~m} / \mathrm{mol})$ and 1-propanol $(150 \mathrm{~mL})$ were added. The mixture was heated at $110{ }^{\circ} \mathrm{C}$ under reflux for $4 \mathrm{~h}$. Then the solution was poured into $2 \mathrm{~N} \mathrm{HCl}(150 \mathrm{~mL})$ at room temperature. The resulting organic layer was separated, washed with brine $(20 \mathrm{~mL})$ and dried over $\mathrm{MgSO}_{4}$. The solvent was evaporated under reduced pressure to give a white solid 2' (yield $63 \%$ ). $\mathrm{cm}^{-1}$.

IR (thin film): $3440(\mathrm{OH}), 2360(\mathrm{C} \equiv \mathrm{C}), 1710(\mathrm{C}=\mathrm{O})$

${ }^{1} \mathrm{H}$ NMR $\left(\mathrm{CDCl}_{3} / \mathrm{TMS}, \delta, 0.0001 \%\right): 11.54(\mathrm{~s}, 1 \mathrm{H}$, $\mathrm{COOH}), 2.31\left(\mathrm{t}, 2 \mathrm{H}, \mathrm{CH}_{2}-\mathrm{COOH}\right), 2.17-2.11(\mathrm{~m}, 2 \mathrm{H})$, $1.92(\mathrm{t}, 1 \mathrm{H}), 1.55-1.44(\mathrm{~m}, 4 \mathrm{H}), 1.33-1.23(\mathrm{~m}, 8 \mathrm{H})$.

\subsubsection{0-Undecyn-1-ol 3'}

10-Undecynic acid 2' (1.6 g, $8.8 \mathrm{~m} / \mathrm{mol})$ was dissolved in $50 \mathrm{~mL}$ diethyl ether and added dropwise to a dispersion of $\mathrm{LiAlH}_{4}(0.4 \mathrm{~g}, 10.2 \mathrm{~m} / \mathrm{mol})$ in $100 \mathrm{~mL}$ of anhydrous diethyl ether. The mixture was stirred for $2 \mathrm{~h}$ at room temperature, and then the excess $\mathrm{LiAlH}_{4}$ was decomposed by adding $20 \mathrm{~mL}$ of water dropwise. A $2 \mathrm{~N}$ $\mathrm{HCl}(30 \mathrm{~mL})$ aqueous solution was added until the $\mathrm{pH}$ was neutral. The resulting organic layer was separated, washed with brine $(20 \mathrm{~mL})$ and dried over $\mathrm{MgSO}_{4}$. The solvent was evaporated under reduced pressure to give a pale-yellow solid 3' (yield $72 \%$ ).

IR (thin film): $3335(\mathrm{OH}), 2358(\mathrm{C} \equiv \mathrm{C}) \mathrm{cm}^{-1}$.

${ }^{1} \mathrm{H} \mathrm{NMR}\left(\mathrm{CDCl}_{3} / \mathrm{TMS}, \delta, 0.0001 \%\right): 3.59(\mathrm{t}, 2 \mathrm{H}$, $\left.\mathrm{CH}_{2} \mathrm{OH}\right), 2.20-2.14(\mathrm{~m}, 4 \mathrm{H}), 1.76(\mathrm{t}, 1 \mathrm{H}, \mathrm{CH}-\mathrm{C})$, $1.56-1.50(\mathrm{~m}, 4 \mathrm{H}), 1.35-1.26(\mathrm{~m}, 8 \mathrm{H})$.

\subsubsection{Aromatic triols 4'a and 4'b}

10-Undecyn-1-ol 3' (0.68 g, $4.0 \mathrm{~m} / \mathrm{mol})$ was dissolved in n-butyl alcohol $(9 \mathrm{~mL})$ and benzene $(150 \mathrm{~mL})$. $\mathrm{PdCl}_{2}(0.15 \mathrm{~g}, 0.85 \mathrm{~m} / \mathrm{mol})$ and $\mathrm{CuCl}_{2}(2.05 \mathrm{~g}, 12 \mathrm{mmol})$ were added. The reaction mixture was heated at $40{ }^{\circ} \mathrm{C}$ and refluxed for $8 \mathrm{~h}$. The resulting mixture was cooled to room temperature and filtered to remove the $\mathrm{PdCl}_{2}$ and $\mathrm{CuCl}_{2}$. The resulting organic layer was separated, washed with brine $(20 \mathrm{~mL})$ and dried over $\mathrm{MgSO}_{4}$. The solvent was evaporated by reduced pressure to give a dark-yellow oil 4'a and 4'b (yield $68 \%$ ).

IR (thin film): $3456(\mathrm{OH}), 1639(\mathrm{C}=\mathrm{C}$ of benzene) $\mathrm{cm}^{-1}$.

${ }^{1} \mathrm{H}$ NMR ( $\left.\mathrm{CDCl}_{3} / \mathrm{TMS}, \delta, 0.0001 \%\right): 6.40(\mathrm{~s}, 3 \mathrm{H}$, $\mathrm{Ph}), 3.64\left(\mathrm{t}, 6 \mathrm{H}, \mathrm{CH}_{2} \mathrm{Ph}\right), 2.29(\mathrm{t}, 6 \mathrm{H}), 1.61-1.24(\mathrm{~m}$, $42 \mathrm{H})$.

${ }^{13} \mathrm{C} \mathrm{NMR}\left(\mathrm{CDCl}_{3} / \mathrm{TMS}, \delta, \mathrm{ppm}\right): 138.22\left(\mathrm{Ph}-\mathrm{CH}_{2}\right)$, 120.35 (Ph-H), $64.11\left(\mathrm{CH}_{2} \mathrm{OH}\right), 39.86,34.35,30.68$, 29.70, 29.08, 28.54, 27.46, 24.96.

\subsection{Synthesis of aromatic triol 4" from erucic acid}

\subsubsection{Dibromide carboxylic acid 1"}

Erucic acid (15.88 g, $33.6 \mathrm{mmol})$ in diethyl ether $(150 \mathrm{~mL})$ was cooled to $0{ }^{\circ} \mathrm{C}$ in an ice-water bath. Bromine $(2.7 \mathrm{~mL}, 52.3 \mathrm{mmol})$ was added dropwise over $30 \mathrm{~min}$. Then the ice-water bath was removed and the solution was stirred for another $2 \mathrm{~h}$ at room temperature. A saturated $\mathrm{Na}_{2} \mathrm{~S}_{2} \mathrm{O}_{3}$ solution $(20 \mathrm{~mL})$ was added to reduce the excess bromine. The resulting organic phase was separated, washed with brine $(20 \mathrm{~mL})$ and dried over $\mathrm{MgSO}_{4}$. The solvent was evaporated under reduced pressure to give a gray solid 1" (yield $78 \%$ ).

IR (thin film): $3425(\mathrm{OH}), 1706(\mathrm{C}=\mathrm{O}) \mathrm{cm}^{-1}$.

${ }^{1} \mathrm{H}$ NMR $\left(\mathrm{CDCl}_{3} / \mathrm{TMS}, \delta, 0.0001 \%\right): 11.89(\mathrm{~s}, 1 \mathrm{H}$, $\mathrm{COOH}), 4.27-4.18(\mathrm{~m}, 2 \mathrm{H}, \mathrm{CH}-\mathrm{Br}), 2.35(\mathrm{t}, 2 \mathrm{H}$, $\mathrm{CH}_{2}-\mathrm{COOH}$ ), 2.10-1.95 (m, 2H, CH-CHBr), 1.65-1.54 $(\mathrm{m}, 2 \mathrm{H}), 1.47-1.26(\mathrm{~m}, 30 \mathrm{H}), 0.89\left(\mathrm{t}, 3 \mathrm{H}, \mathrm{CH}_{3}\right)$.

\subsubsection{Behenolic acid 2"}

The dibromide compound 1" (7.5 g, $15 \mathrm{mmol})$ was dissolved in DMSO (18 mL, $250 \mathrm{mmol}) . \mathrm{KOH}(20 \mathrm{~g}$, $360 \mathrm{mmol})$ and 1-propanol $(150 \mathrm{~mL})$ were added. The mixture was heated at $110{ }^{\circ} \mathrm{C}$ under reflux for $4 \mathrm{~h}$. Then the solution was poured into $2 \mathrm{~N}$ hydrochloric acid $(\mathrm{HCl})$ $(150 \mathrm{~mL})$ at room temperature. The resulting organic layer was separated, washed with brine $(20 \mathrm{~mL})$ and dried over $\mathrm{MgSO}_{4}$. The solvent was evaporated under reduced pressure to give a pale-yellow powder 2" (yield $72 \%)$.

IR (thin film): $3454(\mathrm{OH}), 2361(\mathrm{C} \equiv \mathrm{C}), 1705(\mathrm{C}=\mathrm{O})$ $\mathrm{cm}^{-1}$.

${ }^{1} \mathrm{H}$ NMR $\left(\mathrm{CDCl}_{3} / \mathrm{TMS}, \delta, 0.0001 \%\right): 11.62(\mathrm{~s}, 1 \mathrm{H}$, $\mathrm{COOH}), 2.37\left(\mathrm{t}, 2 \mathrm{H}, \mathrm{CH}_{2}-\mathrm{COOH}\right), 2.15(\mathrm{~m}, 4 \mathrm{H}$, $\left.\mathrm{CH}_{2}-\mathrm{CC}\right), 1.69-1.23(\mathrm{~m}, 30 \mathrm{H}), 0.90\left(\mathrm{t}, 3 \mathrm{H}, \mathrm{CH}_{3}\right)$.

\subsubsection{Behenolic ester 3"}

To a solution of behenolic acid 2" (4.5 g, $12.9 \mathrm{mmol})$ in methanol $(100 \mathrm{~mL})$ was added about $5 \mathrm{~mL}$ concentrated sulphuric acid. The reaction mixture was heated at

$95{ }^{\circ} \mathrm{C}$ and refluxed for $3 \mathrm{~h}$. The resulting organic layer was separated, washed with brine $(20 \mathrm{~mL})$ and 
X. L. CHEN et al.: PREPARATION OF BIO-POLYMERIC MATERIALS, THEIR MICROSTRUCTURES ...

dried over $\mathrm{MgSO}_{4}$. The solvent was evaporated under reduced pressure to give pale-yellow oil 3" (yield $62 \%$ ).

IR (thin film): $2360(\mathrm{C} \equiv \mathrm{C}), 1745(\mathrm{C}=\mathrm{O}), 1170(\mathrm{C}-\mathrm{O})$ $\mathrm{cm}^{-1}$.

${ }^{1} \mathrm{H}$ NMR $\left(\mathrm{CDCl}_{3} / \mathrm{TMS}, \delta, 0.0001 \%\right): 3.66(\mathrm{~s}, 3 \mathrm{H}$, $\left.\mathrm{CH}_{3}-\mathrm{O}\right), 2.30\left(\mathrm{t}, 2 \mathrm{H}, \mathrm{CH}_{2}-\mathrm{COOCH}_{3}\right), 2.13(\mathrm{~m}, 4 \mathrm{H}$, $\left.\mathrm{CH}_{2}-\mathrm{CC}\right), 1.68-1.20(\mathrm{~m}, 30 \mathrm{H}), 0.88\left(\mathrm{t}, 3 \mathrm{H}, \mathrm{CH}_{3}\right)$.

\subsubsection{Aromatic triester 4" $a$ and 4" $b$.}

Behenolic ester 3" (2.8 g, $8.0 \mathrm{mmol})$ were dissolved in n-butyl alcohol $(9 \mathrm{~mL})$ and benzene $(150 \mathrm{~mL}) . \mathrm{PdCl}_{2}$ $(0.15 \mathrm{~g}, 0.85 \mathrm{mmol})$ and $\mathrm{CuCl}_{2}(2.05 \mathrm{~g}, 12 \mathrm{mmol})$ were added. The reaction mixture was heated at $40{ }^{\circ} \mathrm{C}$ and refluxed for $12 \mathrm{~h}$. The resulting mixture was cooled to room temperature and filtered to remove the $\mathrm{PdCl}_{2}$ and $\mathrm{CuCl}_{2}$. The resulting organic layer was separated, washed with brine $(20 \mathrm{~mL})$ and dried over $\mathrm{MgSO}_{4}$. The solvent was evaporated under reduced pressure to give a yellow oil 4"'a and 4"'b (yield $68 \%$ ).

IR (thin film): $1745(\mathrm{C}=\mathrm{O}), 1641(\mathrm{C}=\mathrm{C}$ of benzene), 1174 (C-O) $\mathrm{cm}^{-1}$.

${ }^{1} \mathrm{H}$ NMR $\left(\mathrm{CDCl}_{3} / \mathrm{TMS}, \delta, 0.0001 \%\right): 3.68(\mathrm{~s}, 9 \mathrm{H}$, $\left.\mathrm{CH}_{3}-\mathrm{O}\right), 2.54-2.43\left(\mathrm{~m}, 12 \mathrm{H}, \mathrm{CH}_{2} \mathrm{Ph}\right), 2.32(\mathrm{t}, 6 \mathrm{H}$, $\left.\mathrm{CH}_{2}-\mathrm{COOCH}_{3}\right), 1.70-1.26(\mathrm{~m}, 90 \mathrm{H}), 0.90\left(\mathrm{t}, 9 \mathrm{H}, \mathrm{CH}_{3}\right)$

${ }^{13} \mathrm{C} \mathrm{NMR}\left(\mathrm{CDCl}_{3} / \mathrm{TMS}, \delta, 0.0001 \%\right): 174.41(\mathrm{C}=\mathrm{O})$, $136.71\left(\mathrm{Ph}-\mathrm{CH}_{2}\right), 51.48\left(\mathrm{CH}_{3}-\mathrm{O}\right), 34.13,33.76,31.96$, 31.46 , 30.69, 30.17, 29.71, 29.52, 29.42, 29.36, 29.31, 29.10, 24.97, 22.72, $14.16\left(\mathrm{CH}_{3}\right)$.

\subsubsection{Aromatic triols 5" $a$ and 5" $b$.}

Aromatic triester 5" $(2.1 \mathrm{~g}, 2.0 \mathrm{mmol})$ were dissolved in $50 \mathrm{~mL}$ diethyl ether and added dropwise to a dispersion of $\mathrm{LiAlH}_{4}(0.4 \mathrm{~g}, 10.2 \mathrm{mmol})$ in $100 \mathrm{~mL}$ of anhydrous diethyl ether. The mixture was stirred for $2 \mathrm{~h}$ at room temperature, and then the excess $\mathrm{LiAlH}_{4}$ was decomposed by adding $20 \mathrm{~mL}$ of water dropwise. A $2 \mathrm{~N}$ $\mathrm{HCl}(30 \mathrm{~mL})$ aqueous solution was added until the $\mathrm{pH}$ was neutral. The resulting organic layer was separated, washed with brine $(20 \mathrm{~mL})$ and dried over $\mathrm{MgSO}_{4}$. The solvent was evaporated under reduced pressure to give a pale-yellow oil 5"'a and 5"b (yield $88 \%$ ).

IR (thin film): $3430(\mathrm{OH}), 1465(\mathrm{C}=\mathrm{C}$ of benzene) $\mathrm{cm}^{-1}$.

${ }^{1} \mathrm{H}$ NMR $\left(\mathrm{CDCl}_{3} / \mathrm{TMS}, \delta, 0.0001 \%\right): 3.63(\mathrm{t}, 6 \mathrm{H}$, $\left.\mathrm{CH}_{2} \mathrm{OH}\right), 2.56-2.40(\mathrm{~m}, 12 \mathrm{H}), 1.64-1.26(\mathrm{~m}, 96 \mathrm{H}), 0.89$ (t, 9H, $\mathrm{CH}_{3}$ ).

${ }^{13} \mathrm{C}$ NMR ( $\left.\mathrm{CDCl}_{3} / \mathrm{TMS}, \delta, 0.0001 \%\right): 136.71$ $\left(\mathrm{PhCH}_{2}\right), 63.06\left(\mathrm{CH}_{2} \mathrm{OH}\right), 34.12,32.81,32.61,31.96$, 31.49 , 30.68, 29.70, 29.51, 29.42, 29.26, 25.75, 24.97, $22.70,22.70,19.15,14.13\left(\mathrm{CH}_{3}\right)$.

\subsection{Synthesis of polyurethanes}

Polyurethane powders were prepared by reacting aromatic triol with diisocyanate at different molar ratios of the $\mathrm{OH}$ group to the $\mathrm{NCO}$ group. The desired $\mathrm{OH} / \mathrm{NCO}$ molar ratio satisfies Equation (1):

$$
M_{\text {ratio }}=\frac{W_{\text {polyol }} / E W_{\text {polyol }}}{\left(W_{\mathrm{PU}}-W_{\text {polyol }}\right) / E W_{\text {disocyanate }}}
$$

where $W_{\text {polyol }}$ is the weight of the polyol, $E W_{\text {polyol }}$ is the equivalent weights of polyol, $W_{\mathrm{PU}}$ is the total weight of polyurethane, and $E W_{\text {diisocyanate }}$ is the equivalent weight of the diisocyanate.

The equivalent weight for the diisocyanate was calculated based on the molar mass and was $E W_{\text {disocyanate }}=$ $250 \mathrm{~g} / \mathrm{mol}$. The equivalent weights of aromatic triol were determined using Equation (2):

$$
\begin{aligned}
& E W_{\text {polyol }}=\frac{\text { molecular weight of } \mathrm{KOH} \times 1000}{\text { OH Number }}= \\
& =\frac{56110}{\text { OH Number }} \text { g per mole of hydroxyl group }
\end{aligned}
$$

The weights of the polyol and diisocyanate were calculated using the above-calculated equivalent weight.

Polyurethane elastomers are block copolymers and their domain structure can be controlled through the selection of the materials and their relative proportions. The polyurethanes were prepared using a single-stage process. In our investigation the hard-segment composition was controlled by the molar ratios of polyol/diisocyanate/diol and aromatic triol used in the synthesis. ${ }^{18}$ The molar ratios of the $\mathrm{OH}$ group to the diisocyanate (NCO) group chosen for the formulations were 0.9. The $\mathrm{OH}_{\text {diol }} / \mathrm{OH}_{\text {aromatic triol }}$ molar ratio used was 1.0/2.0 in each of the synthesized polyurethane samples. After 10 min of mixing the appropriate amount of aromatic triols and chain extender (BD) at $75{ }^{\circ} \mathrm{C}$, diisocyanate at the $\mathrm{OH} / \mathrm{NCO}$ ratio of 0.9 was added. The mixture was cured for $2 \mathrm{~h}$ at $75^{\circ} \mathrm{C}$ and then post-cured at $110{ }^{\circ} \mathrm{C}$ for $16 \mathrm{~h}$.

\subsection{Measurements and analysis}

The X-ray diffraction (XRD) patterns obtained on an X-ray diffractometer (type Bruker AXS D8) using $\mathrm{Cu}-K \alpha 1$ radiation at a scan rate $(2 \theta)$ of $0.02^{\circ} \mathrm{s}^{-1}$ were used to determine the identity of any phase present and the crystallite size. The accelerating voltage and the applied current were $15 \mathrm{kV}$ and $20 \mathrm{~mA}$, respectively.

The Fourier-transform infrared spectroscopy (FTIR) spectra were recorded on a Bruker Tensor 27 spectrometer in the range $400-4000 \mathrm{~cm}^{-1}$ using $\mathrm{KBr}$ disks. ${ }^{1} \mathrm{H}$ NMR and ${ }^{13} \mathrm{C}$ NMR were recorded on Bruker Advance III $300 \mathrm{MHz}$ spectrometers with $\mathrm{CDCl}_{3}$ as a solvent.

DSC measurements were carried out on a Diamond DSC instrument (TA instruments, DE, USA), equipped with a refrigerated cooling system. The samples were heated at a rate of $10{ }^{\circ} \mathrm{C} / \mathrm{min}$ from $25{ }^{\circ} \mathrm{C}$ to $200{ }^{\circ} \mathrm{C}$ to erase the thermal history and cooled down to $-65^{\circ} \mathrm{C}$ at cooling rate of $5{ }^{\circ} \mathrm{C} / \mathrm{min}$. The DSC experiments were carried out with a liquid-nitrogen cooler under a drynitrogen atmosphere. 
For thermal stability analysis, $10 \mathrm{mg}$ of the dried polyurethanes powders were used in TG-DTA thermal analyzer (type PerkinElmer Diamond TG/DTA, America) at a heating rate of $10{ }^{\circ} \mathrm{C} / \mathrm{min}$ from $20{ }^{\circ} \mathrm{C}$ to $800{ }^{\circ} \mathrm{C}$ in an inert-gas atmosphere.

\section{RESULTS AND DISCUSSION}

\subsection{Synthesis of bio-based aromatic triols}

The synthesis of triol monomers from oleic acid, erucic acid and 10-undecenoic through a cyclotrimerization reaction yielded a mixture of asymmertrical and symmetrical molecules (Chart 1). Bio-based aromatic triols oleic acid-based aromatic triols (O-BAT), erucic acid-based aromatic triols (E-BAT) and 10-undecenoicbased aromatic triols (U-BAT) were synthesized by two different methods. Alkyne alcohol derivatives were obtained in moderate yields from the corresponding fatty acids by bromation, dehydrobromination, and reduction of carboxylic acid using well-established procedures (Scheme1). Alkyne fatty derivatives were obtained in moderate yields from the corresponding fatty acids by bromation, dehydrobromination, and esterification using well-established procedures (Scheme1). ${ }^{9}, 12$ Cyclotrimerization of the 10-undecyn-1-ol 3' and behenolic ester 3" were carried out using $\mathrm{PdCl}_{2}$ as a transition-metal catalyst. However, when cyclotrimerization of stearoyl alcohol 3 was carried out under the same conditions, some side products were slowly generated or no indication of the trimer formation was obtained. The reaction was then carried out using $\mathrm{Pd} / \mathrm{C}$ as a transition-metal catalyst, and the expected product was obtained in moderate yields. ${ }^{10,11}$

Transition-metal-catalyzed cyclotrimerization of alkynes can be considered as one of the most powerful and general methodologies used to assemble arene rings, and a large number of transition-metal catalysts have been developed for alkyne cyclotrimerization in organic media. ${ }^{12,24-25}$ A simple method utilizes a heterogeneous $\mathrm{Pa} / \mathrm{C}$ catalyst in a nitrogen atmosphere with refluxing THF as the solvent and commercial grade chlorotri-

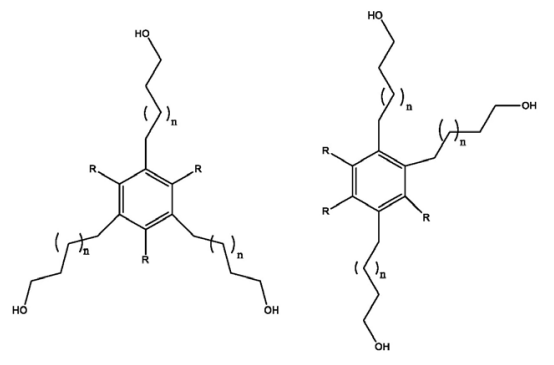

(A) Oleic acid and derivatives: $\mathrm{n}=5, \mathrm{R}=\left(\mathrm{CH}_{2}\right)_{7} \mathrm{CH}_{3}$ (B) Erucic acid and derivatives: $n=9, \mathrm{R}=\left(\mathrm{CH}_{2}\right)_{7} \mathrm{CH}_{3}$

(C) 10-undecenoic acid and derivatives: $n=6, R=H$

Chart 1: Chemical structures of aromatic triols monomers obtained by oleic acid, erucic acid and 10-undecenoic, respectively Grafikon 1: Kemijske strukture aromatičnih triol monomerov, dobljenih z oleinsko kislino, eruka kislino in 10 -undekenojsko kislino methylsilane. ${ }^{10,26}$ Cyclotrimerization of Stearoyl alcohol 3 was carried out following this procedure, and the symmetric and asymmetric isomers, such as aromatic triols $4 \mathrm{a}$ and $4 \mathrm{~b}$, have almost identical IR or ${ }^{13} \mathrm{C}$ NMR spectra in $\mathrm{CDCl}_{3}$. The formation of the aromatic derivative was confirmed by the appearance of the signal at $0.013677 \%$ in the ${ }^{13} \mathrm{C}$ NMR spectrum corresponding to the aromatic core. The two compounds could not be separated by flash chromatography due to their similar polarities. Therefore, the presence of two compounds could not be ruled out.

The preparation of benzene derivatives via the palladium-chloride-catalyzed cyclotrimerization of alkynes in the presence of $\mathrm{CuCl}_{2}$ has been described as a smooth and regioselective method. ${ }^{12}$ When the cyclotrimerization of 10-undecyn-1-ol 3' was carried out using $\mathrm{PdCl}_{2}$ and $\mathrm{CuCl}_{2}$ as transition-metal catalysts, a 1,3,5-trisubstituted benzene derivative was obtained regioselectively in a moderate yield. The appearance of signals at $0.000639 \%$ in the ${ }^{1} \mathrm{H}$ NMR spectrum and $0.012035 \%$ and $0.013763 \mathrm{ppm}$ in the ${ }^{13} \mathrm{C}$ NMR spectrum confirms the formation of the symmetric product.

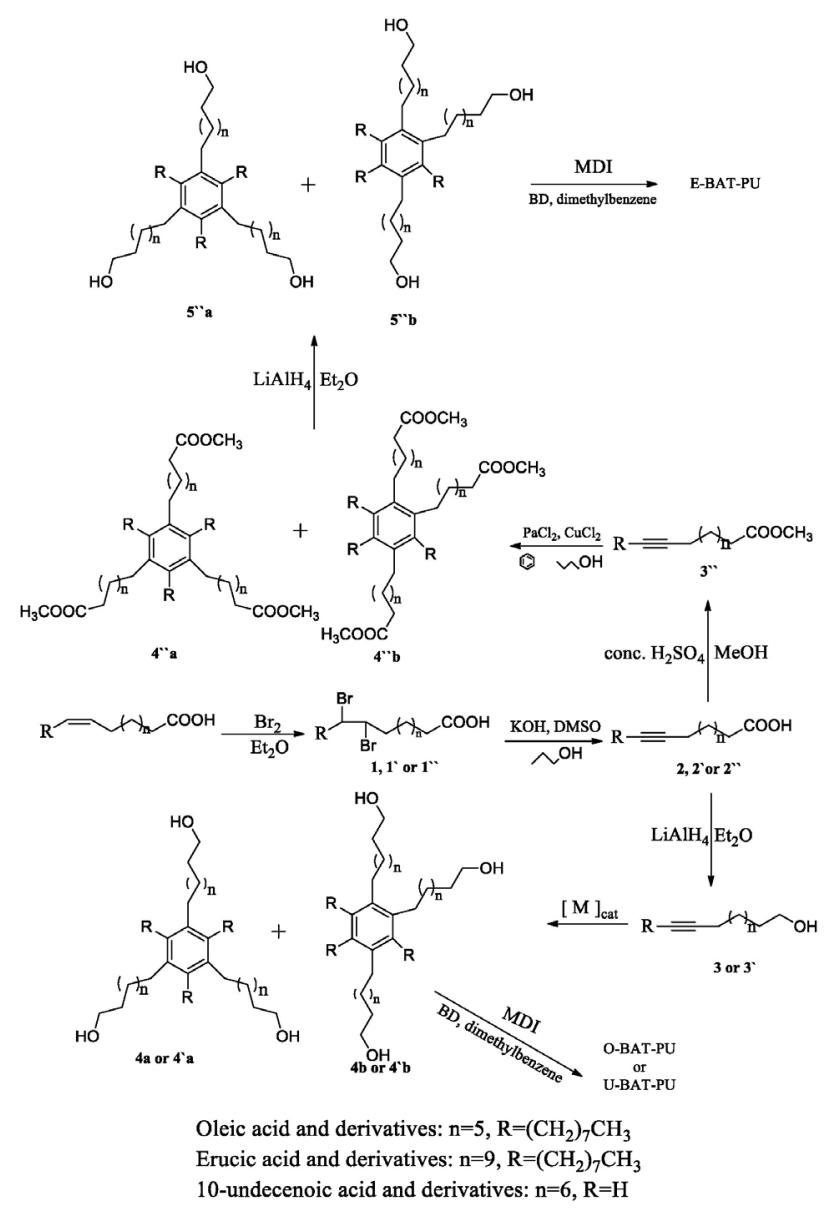

Scheme 1: Synthesis of aromatic triols from oleic acid, erucic acid and 10-undecenoic acid, respectively

Shema 1: Sinteza aromatičnih triol iz oleinske kisline, eruka kisline in 10-undekenojske kisline 


\section{L. CHEN et al.: PREPARATION OF BIO-POLYMERIC MATERIALS, THEIR MICROSTRUCTURES ...}

The attempt to cyclotrimerize behenolic ester 3" via $\mathrm{Pa} / \mathrm{C}$ catalyst in nitrogen atmosphere with refluxing THF as the solvent and chlorotrimethylsilane, some side products were slowly generated. The preparation of benzene derivatives via the palladium-chloride-catalyzed cyclotrimerization of alkynes in the presence of $\mathrm{CuCl}_{2}$ has been described as a smooth and regioselective method. ${ }^{12,27-28}$ When we applied the reaction to behenolic ester 3", the symmetric and asymmetric isomers, such as aromatic triols 4"a and 4" b, have almost identical IR or ${ }^{13} \mathrm{C}$ NMR spectra in $\mathrm{CDCl}_{3}$. The formation of the aromatic derivative was confirmed by the appearance of the signal at $0.013671 \%$ in the ${ }^{13} \mathrm{C}$ NMR spectrum corresponding to the aromatic core. The two compounds could not be separated by flash chromatography due to their similar polarities. Therefore, the presence of two compounds could not be ruled out. The reaction can also proceed with behenolyl alcohol. However, when cyclotrimerization of the behenolyl alcohol was carried out in the same conditions, a lot of side products were slowly generated and the yields of aromatic triester 4"a and 4"b were lower. So, aromatic ester derivatives were used as a starting material for the reduction of the carboxylate groups to synthesize two triols with primary hydroxyl groups.

\subsection{Synthesis and characterization of polyurethanes}

Vegetable-oil-based polyols have been widely used to produce segmented and non-segmented polyurethanes. ${ }^{19-22}$ Segmented polyurethanes are elastomeric block copolymers that generally exhibit a phase-segregated morphology made up of soft rubbery segments and hard glassy or semi-crystalline segments. ${ }^{23,24}$ The soft segment usually consists of polyether or polyester diols, whereas the hard segment consists of the diisocyanate component and a low molecular weight consists of the diisocyanate component and a low-molecular-weight chain extender. The advantage of segmented polyurethanes is that their

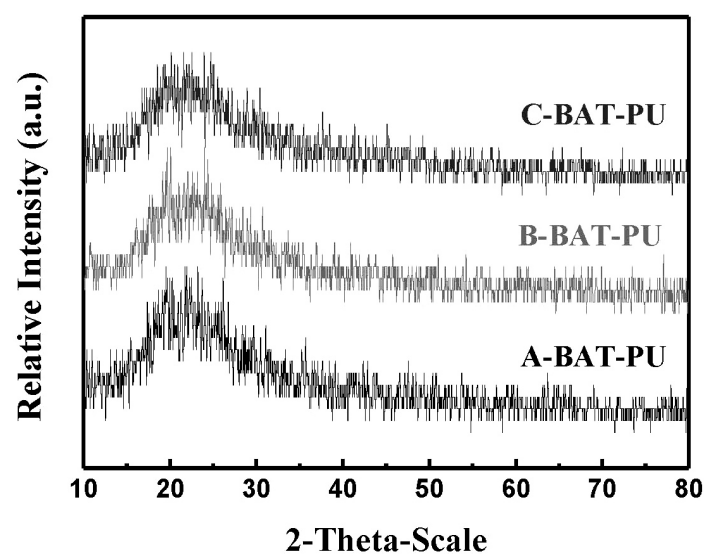

Figure 1: Wide-angle X-ray diffraction patterns of: a) O-BAT, b) E-BAT and c) U-BAT polyurethane

Slika 1: Širokokotna rentgenska difrakcija: a) O-BAT, b) E-BAT in c) U-BAT poliuretana segmental and domain structure can be controlled over a considerable range through the selection of the materials, their relative proportions, and the processing conditions. ${ }^{12}$

In the study, bio-based polyurethanes were prepared using the one-shot technique from O-BAT, E-BAT or U-BAT, BD as a chain extender, and MDI as a coupling agent. The bio-based aromatic triols/MDI part is considered as the soft phase, even though its glass transition is above room temperature (Table 1). These hard segments are polar, crystallizable and likely to form a separate phase if the hard-segment content is high enough. The chemical composition and hard-segment content of the synthesized polyurethanes are also shown in Table $\mathbf{1 .}$ The $\mathrm{OH} / \mathrm{NCO}$ molar ratio was kept at 1.5. Reactants were mixed at $75{ }^{\circ} \mathrm{C}$ and cured at this temperature for $2 \mathrm{~h}$ and post-cured at $110{ }^{\circ} \mathrm{C}$ for $18 \mathrm{~h}$ to give the polyurethanes.

Table 1: Formulations and hardness of the polyurethanes obtained Tabela 1: Formulacija in trdota dobljenega poliuretana

\begin{tabular}{|c|c|c|c|}
\hline Sample code & $\begin{array}{c}\text { Ratio } \\
\text { (OH:NCO) }\end{array}$ & $\begin{array}{c}\text { Ratio } \\
\text { (Polyol/BD/M } \\
\text { DI) }\end{array}$ & $\begin{array}{c}\text { \% Hard } \\
\text { segment }\end{array}$ \\
\hline O-BAT-PU & 0.9 & $1: 3: 3$ & 56.9 \\
\hline E-BAT-PU & 0.9 & $1: 3: 3$ & 52.1 \\
\hline U-BAT-PU & 0.9 & $1: 3: 3$ & 67.6 \\
\hline
\end{tabular}

* The hard-segment percentage is calculated as the $w / \%$ of $\mathrm{BD}$ and MDI per total material weight

To investigate the molecular structure of polyurethanes WAXD and FTIR were employed. The amorphous character of both the asymmetric and symmetric polyurethanes was verified by WAXD (Figure 1). All the samples show similar WAXD curves with a broad peak at about $2 \theta \approx 22^{\circ}$. This broad peak is a typical characteristic of amorphous polymers ${ }^{12,13,15-17}$, which confirms that there are no crystals in O-BAT-PU, E-BAT-PU and U-BAT-PU.

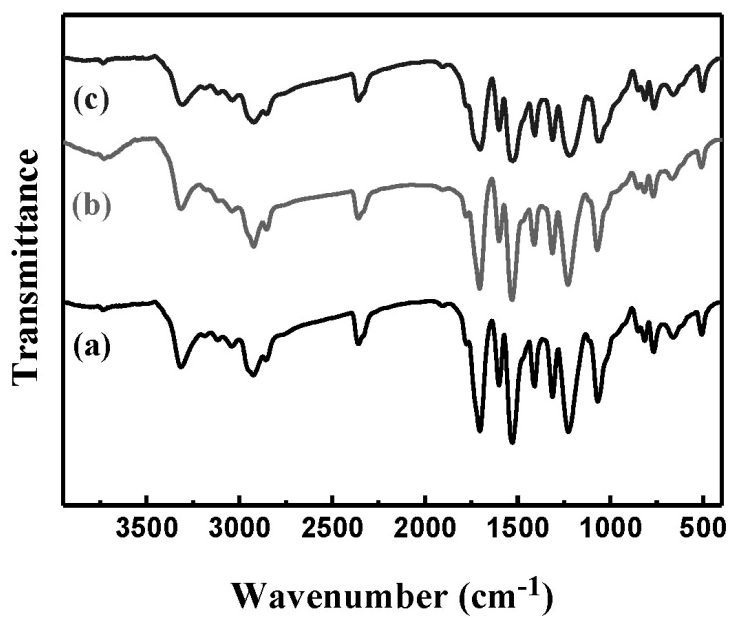

Figure 2: FTIR spectra of: a) O-BAT-PU, b) E-BAT-PU, and c) U-BAT-PU

Slika 2: FTIR-spektri: a) O-BAT-PU, b) E-BAT-PU in c) U-BAT-PU 
The FTIR spectra for O-BAT-PU, E-BAT-PU, and U-BAT-PU are shown in Figure 2. From Figure 2, it is clear that the spectra are similar for the PUs prepared from the same diisocyanate but different aromatic triols sources. The unreacted diisocyanate (NCO group) is clearly shown by a peak centered at $2362 \mathrm{~cm}^{-1}$. A strong stretching band located at around $3317 \mathrm{~cm}^{-1}$ characteristic of the $\mathrm{N}-\mathrm{H}$ group and a stretching vibration band centered around $1708 \mathrm{~cm}^{-1}$ characteristic of the $\mathrm{C}=\mathrm{O}$ group are present in the FTIR spectra. ${ }^{7,8,15}$ There are also two stretching regions attributed to the $\mathrm{C}=\mathrm{O}$ group. The band centered at around $1768 \mathrm{~cm}^{-1}$ corresponds to the free carbonyl group. These results indicated that the three kinds of PU materials undergo physical bonding. ${ }^{16,18}$

\subsection{Thermal stability of polyurethanes}

Thermal analysis of the polyurethanes obtained was performed to provide insights into the morphological structure of the material. Figure 3 shows the DSC thermogram for the polyurethanes. There were two endothermic peaks at about $45-50{ }^{\circ} \mathrm{C}$ and $175-190{ }^{\circ} \mathrm{C}$. The glass-transition temperature of the samples measured by DSC was $45-50{ }^{\circ} \mathrm{C}$. The transition appeared in the region from $45{ }^{\circ} \mathrm{C}$ to $50{ }^{\circ} \mathrm{C}$ and were attributed to the soft-segment glass-transition temperature $\left(T_{\mathrm{g}}\right)$. The $T_{\mathrm{g}}$ value is a measure of relative purity of the soft-segment regions; when there are hard segments dispersed in the soft domains, the $T_{\mathrm{g}}$ is raised. ${ }^{12}$ The addition of bifunctional components such as MDI/BD reduces the cross-linking density, but increases the phenyl ring content. In principle, a reduced cross-linking density should decrease the $T_{\mathrm{g}}$, but an increased aromatic content should have the opposite. ${ }^{12}$ The peak in the region from $175{ }^{\circ} \mathrm{C}$ to $190{ }^{\circ} \mathrm{C}$ was ascribed to the melting point of hard-segment domains, which supports the development of a phase-separated morphology and

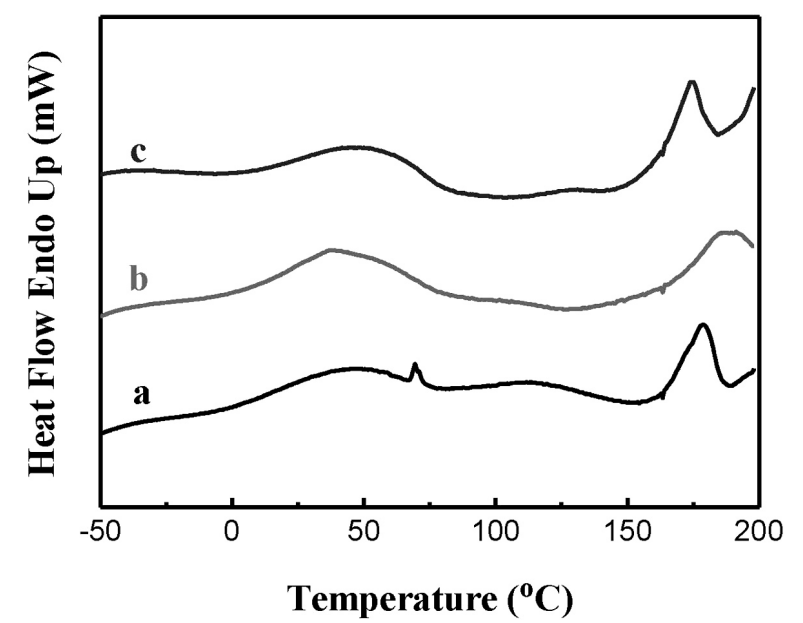

Figure 3: DSC thermograms $\left(10{ }^{\circ} \mathrm{C} / \mathrm{min}\right)$ of: a) O-BAT-PU, b) E-BAT-PU, and c) U-BAT-PU

Slika 3: DSC-termogrami $\left(10{ }^{\circ} \mathrm{C} / \mathrm{min}\right)$ : a) O-BAT-PU, b) E-BAT-PU in c) U-BAT-PU

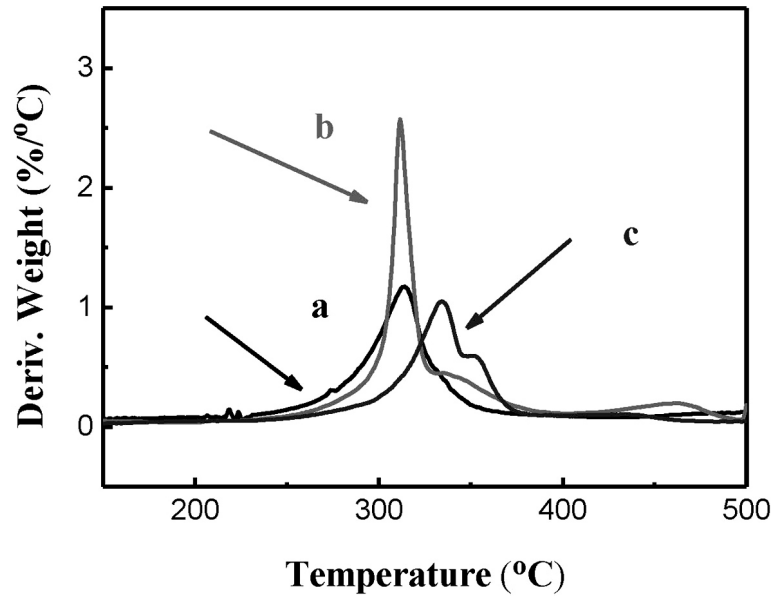

Figure 4: DTG curves of: a) O-BAT-PU, b) E-BAT-PU, and c) U-BAT-PU

Slika 4: DTG-krivulje: a) O-BAT-PU, b) E-BAT-PU in c) U-BAT-PU

indicates that the hard-segment content is high enough to achieve phase separation. ${ }^{12}$

TGA is the most favored technique for the evaluation of the thermal stability of polymers. Polyurethanes have a relatively low thermal stability, mainly because the presence of urethane bonds. From the DTG curves it can be seen that in nitrogen only one process occurs during thermal degradation. G. Lligadas et al. ${ }^{12}$ observed a similar behavior in the case of vegetable-oil-based polyurethanes. They showed that poly-(oxypropylene)based polyurethanes degrade in a single step, whereas vegetable-oil-based polyurethane shows one-step decomposition.,7,15 Figure 4 shows the DTG curve and Figure 5 shows the TGA curves of different polyurethanes, which reveals a degradation stage at temperatures between $300{ }^{\circ} \mathrm{C}$ and $400{ }^{\circ} \mathrm{C}$. The results are similar to the three bio-based polyurethanes systems. That can be associated with the decomposition of urethane bonds, which takes place through the dissociation to diisocyanate and alcohol, the formation of primary amines and olefins, or the formation of secondary amines. ${ }^{16,18}$

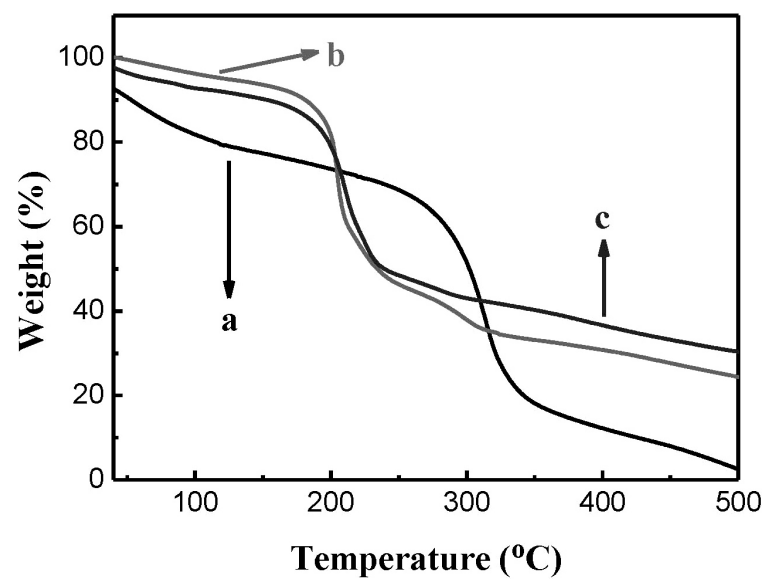

Figure 5: TGA curves of: a) O-BAT-PU, b) E-BAT-PU, and c) U-BAT-PU

Slika 5: TGA-krivulje: a) O-BAT-PU, b) E-BAT-PU in c) U-BAT-PU 


\section{CONCLUSIONS}

Bio-based aromatic triols, O-BAT, E-BAT and U-BAT have been synthesized using two different methods. It is demonstrated that alkyne alcohol derivatives can be obtained in the moderate yields from the corresponding fatty acids by bromation, dehydrobromination, and reduction of carboxylic acid, and alkyne fatty derivatives can also be obtained in moderate yields from the corresponding fatty acids by bromation, dehydrobromination, and esterification. Such a synthesis methodology has indicated a practical feasibility of utilizing the new bio-based aromatic triols for the production of bio-based polyurethanes. The crystalline structure and thermal stability of these polyurethanes have been compared to their counterparts made from a similar O-BAT, E-BAT, and U-BAT, respectively. The corresponding polyurethane networks with hard-segment have been further prepared by the reaction of the polyol, $\mathrm{BD}$, and MDI. The synthesized materials have been characterized using the spectroscopic techniques, WAXD, DSC and TG-DTA. The results have showed that it is possible to exploit renewable resources to achieve environmentfriendly green materials.

\section{REFERENCES}

${ }^{1}$ L. Hu, A. Zhang, Y. Yu, Z. Zheng, S. Du, X. Cheng, Synthesis of hybrid crosslinked polyphosphazenes and investigation of their properties, Iran. Polym. J., 23 (2014), 689-698

${ }^{2}$ A. S. Singha, H. Kapoor, Effects of plasticizer/cross-linker on the mechanical and thermal properties of starch/PVA blends, Iran. Polym. J., 23 (2014), 655-662

${ }^{3}$ S. J. Li, L. Bouzidi, S. S. Narine, Synthesis and physical properties of triacylglycerol oligomers: examining the physical functionality potential of self-metathesized highly unsaturated vegetable oils, Ind. Eng. Chem. Res., 52(2013), 2209-2219

${ }^{4}$ L. Raghunanan, S. S. Narine, Influence of structure on chemical and thermal stability of aliphatic diesters, J. Phys. Chem. B 117(2013), 14754-14762, doi:10.1021/jp409062k

${ }^{5}$ L. Raghunanan, J. Yue, S. S. Narine, Synthesis and characterization of novel diol, diacid and di-isocyanate from oleic acid, J. Am. Oil Chem. Soc. 91(2014), 349-356, doi:10.1007/s11746-013-2376-Z

${ }^{6}$ M. Desroches, M. Escouvois, R. Auvergne, S. Caillol, B. Boutevin, From vegetable oils to polyurethanes: synthetic routes to polyols and main industrial products. Polym Rev 52 (2012): 38-79, doi:10.1080/15583724.2011.640443

${ }^{7}$ P. C. Blasco, J. M. M. Martinez, I. V. Antoniac, Synthesis and characterization of polyurethane sealants containing rosin intended for sealing defect in annulus for disc regeneration, Int. J. Adhes. 42 (2013), 11-20, doi:10.1016/j.ijadhadh.2012.11.011

${ }^{8}$ D.V. Palaskar, A. Boyer, E. Cloutet, J. F. L. Meins, B. Gadenne, C. Alfos, C. Farcet, H. Cramail, Original diols from sunflower and ricin oils: synthesis, characterization, and use as polyurethane building blocks, J. Polym. Sci. Pol. Chem., 50 (2012) 1766-1782, doi:10.1002/pola.25944

${ }^{9}$ G. Lligadas, J. C. Ronda, M. Galia, V. Cadiz, Plant oils as platform chemicals for polyurethane synthesis: current state-of-the-art, Biomacromolecules, 11 (2008) 2825-2835
${ }^{10}$ H. Baumann, M. Bühler, H. Fochem, Natural Fats and Oils - Renewable Raw Materials for the Chemical Industry, Angewandte Chemie International Edition in English, 27 (1988), 41-62

${ }^{11}$ J. Yue, S.S. Narine, Synthesis of aromatic triols and triacids from oleic and erucic acid: separation and characterization of the asymmetric and symmetric isomers, Chem. Phys. Lipids, 152 (2008), 1-8, doi:10.1016/j.chemphyslip.2007.11.002

${ }^{12}$ G,. Lligadas, J. C. Ronda, M. Galia, V. Cadiz, Polyurethane networks from fatty-acid-based aromatic triols: synthesis and characterization. Biomacromolecules , 8 (2007), 1858-1864, doi:10.1021/bm070157k

${ }^{13}$ M. J. Dumont, S. S. Narine, Physical properties of new polyurethanes foams from benzene polyols synthesized from erucic acid, J. Appl. Polym. Sci., 118 (2010), 3211-3217, doi:10.1002/app.32542

${ }^{14}$ G,. Ligadas, J. C. Ronda, M. Galia, V. Cadiz, Oleic and undecylenic acids as renewable feedstocks in the synthesis of polyols and polyurethanes, Polymers 2 (2010), 440-453, doi:10.3390/polym2040440

${ }^{15}$ L. Hojabri, X. H. Kong, S. S. Narine, Fatty acid-derived diisocyanate and biobased polyurethane produced from vegetable oil: synthesis, polymerization, and characterization, Biomacromolecules, 10 (2009), 884-891, doi:10.3390/polym2040440

${ }^{16}$ M. J. Dumont, X. Kong, S. S. Narine, Polyurethanes from benzene polyols synthesized from vegetable oils: dependence of physical properties on structure, J. Appl. Polym. Sci., 117 (2010), 3196-3203

${ }^{17}$ L. Hojabri, X. H. Kong, S. S. Narine, Novel long chain unsaturated diisocyanate from fatty acid: synthesis, characterization, and application in bio-based polyurethane, J. Polym. Sci. Pol. Chem., 48 (2010), 3302-3310, doi:10.1002/pola.24114

${ }^{18} \mathrm{~S}$. Oprea, Synthesis and properties of polyurethane elastomers with castor oil as crosslinker, J. Am. Oil Chem. Soc., 87 (2010), 313-320, doi:10.1007/s11746-009-1501-5

${ }^{19}$ J. H. Li, Y. Liang, Y. X. Xie, Mild and selective palladium-catalyzed dimerization of terminal alkynes to form symmetrical (Z,Z)-1,4-dihalo-1,3-dienes, J. Org. Chem., 69 (2004), 8125-8127, doi:10.1021/ jo0486645

${ }^{20}$ J. H. Li, S. Tang, Y. X. Xie, General and selective synthesis of (Z)-3-haloacrylates via palladium-catalyzed carbonylation of terminal alkynes, J. Org. Chem., 70 (2005), 477-479, doi:10.1021/ jo048358r

${ }^{21}$ J. H. Li, H. F. Jiang, M. C. Chen, $\mathrm{CuCl}_{2}$-Induced regiospecifical synthesis of bezene derivatives in the palladium-catalyzed cyclotrimerization of alkynes, J. Org. Chem., 66 (2001), 3627-3629, doi:10.1021/jo0017382

${ }^{22}$ H. Dietl, H. Reinheimer, J. Moffat, P. M. Maitlis, Reactions of acetylenes with noble-metal halides, VIII, The palladium chloride catalyzed trimerization of 2-butyne and 1-phenyl-1-propyne, J. Am. Chem. Soc., 92 (1970), 2276-2285, doi:10.1021/ja00711a013

${ }^{23}$ J. S. Cheng, H. F. Jiang, Palladium-catalyzed regioselective cyclotrimerization of acetylenes in supercritical carbon dioxide, Eur. J. Org. Chem., 3 (2004), 643-646, doi:10.1002/ejoc.200300299

${ }^{24}$ M. A. R. Meier, J. O. Metzger, U. S. Schubert, Plant oil renewable resources as green alternatives in polymer science, Chem. Soc. Rev., 36(2007), 1788-1802, doi:10.1039/b703294c

${ }^{25}$ L. M. D. Espinosa, M. A. R. Meier, Plant oils: the perfect renewable resource for polymer science?!, Eur. Polym. J., 47 (2011), 837-852, doi:10.1016/j.eurpolymj.2010.11.020

${ }^{26}$ A. Gandini, The irruption of polymers from renewable resources on the scene of macromolecular science and technology, Green Chem., 13 (2011), 1061-108, doi:10.1039/c0gc00789g

${ }^{27}$ Y. Xia, R. C. Larock, Vegetable oil-based polymeric materials: synthesis, properties, and applications, Green Chem., 12 (2010), 1893-1909, doi:10.1039/c0gc00264j

${ }^{28}$ A. K. Jhingan, W. F. Maier, Homogeneous catalysis with a heterogeneous Pd catalyst, An effective method for the cyclotrimerization of alkynes, J. Org. Chem., 52 (1987), 1161-1165, doi:10.1021/ jo00382a039 